\title{
Cultivating Social Science Research in Vietnam: A Case of Collaboration between a Private Research Institute with International and Domestic Research Entities
}

\author{
Hiep-Hung Pham*, Anh-Duc Hoang** \\ EdLab Asia Educational Research and Development Centre, Hanoi, Vietnam \\ "hiep@ researchcoach.edu.vn,
}

\begin{abstract}
Developing research groups within universities and science-technology institutions is one topic that gained a special interest in recent times. In this article, we will present our experience of building a research team in the field of Social Science at EdLab Asia Educational Research and Development Centre (EdLab Asia), a young research institute which achieved several initial results after one year of establishment: 14 published works in the journals from Clarivate WOS and Scopus list, between the time from Sept 2019 to Sept 2020. This article will present the goals, strategies, structure, and operating principles of EdLab Asia. Policy implications for universities and sciencetechnology institutions in educational science in particular, and social science in general will be mentioned at the end of this article.
\end{abstract}

Keywords: Social science; Educational science; International publication; Research collaboration; EdLab Asia

\section{Introduction}

International integration in scientific research at universities and science-technology institutions is one of the special consideration topics in recent times (Pham, 2020; Vuong, 2019). In the wake of global integration, one of the most important factors is the scientists are able to publish their works in credible sources of data directories like Clarivate WOS and Scopus (from now will be referred to simply as international publication). Over the last few years, governmental management units have issued many programs, regulations toward international publications such as:

(i) The National Foundation for Science and Technology Development (NAFOSTED) officially came into operation (in 2008);

(ii) New regulation about Doctoral training (in 2017);

(iii) New regulation about professor and assistant professor titleship (in 2018) (Pham, 2020; Vuong, 2019).

Besides, government units together with universities and science-technology institutions themselves have also issued many approaches to improve research capacity, promote international cooperation and publication. In this article, we will present our experience of building a research team in the field of Social Science at EdLab Asia Educational Research and Development Centre (EdLab Asia), a young research institute which achieved several initial results after one year of establishment: 14 published works in the journals from Clarivate WOS and Scopus list, between the time from Sept 2019 to Sept 2020. This essay will present the goals, strategies, structure and operating principles of EdLab Asia. Policy implications for universities and science-technology institutions in educational science in particular, and social science in general will be mentioned at the end of this article.

\section{The educational science research background in Vietnam recent years}

There is an undeniable fact that compared to the international integration process, Vietnam educational science, even most of other fields in social sciences, goes in a slow progress (Nguyen et al., 2020; Tran et al., 2020). (Figure 1 below). It was not until 2013 that the number of international 
publications in Vietnam educational science reached the 2-digit number (12 publications. During 1991-2018, although the volume of international publication indexed in Clarivate WOS databases, including SSCI, ESCI, BKCI and CPCI of Vietnamese authors in the field of educational science has increased significantly and exponentially from 2015 onwards, it seemed relatively modest. Perhaps, behind this result is pocket-size but well worth the international integration effort of all scientific research in general and social sciences in particular.

Figure 1: Number of published articles about educational science from Vietnamese authors being indexed at SSCI, ESCI, BKCI and CPCI, 1991-2018

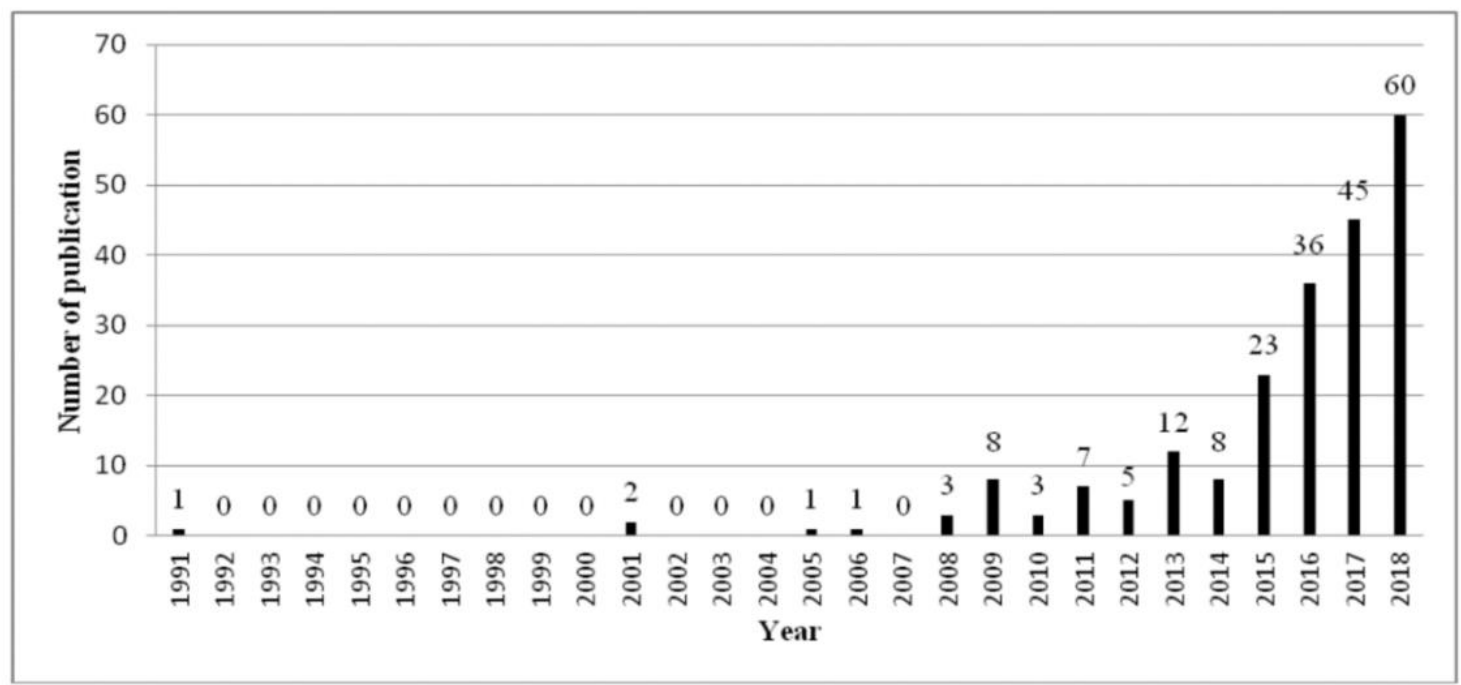

Source: Vuong et al. (2010)

\section{The role of research groups in the context of international integration}

One of the most recent topics of interest that crossed all Vietnamese tertiary education doers' minds is how to create research groups as well as science-technology organizations. Reasoning for this desire is not all other things than the instant answer for comfortably outpacing Vietnam science's rivals in a sprint throughout the finishing line of international integration. Moreover, once the Ministry of Education and Training announced its engagement to the specific circular for building research groups in the higher education system, it would form the backbone of higher international publishing and research capacity. Although Vietnamese government has just drawn this circular in outline, many research groups from universities already existed in embryo (Table 1 below). These research groups operated under two main types as Milojevi (2014) summarized: The first type followed "closed" form and played a role as a fixed department with the number of full-time "flexible lecturers" staff members; the second type also possess "flexible lecturers" but going "open" direction and formal or informal staff members varies from full-time to part-time such as postgraduate, $\mathrm{PhD}$ student or researchers of different groups.

Table 1: The establishment of research groups at Vietnamese universities (2014-2017)

\begin{tabular}{|l|l|}
\hline \multicolumn{1}{|c|}{ University } & \multicolumn{1}{c|}{ Information } \\
\hline $\begin{array}{l}\text { Thuy Loi University } \\
\text { (TLU, 2020) }\end{array}$ & $\begin{array}{l}\text { In 2020, Thuy Loi University has launched 4 strong research groups } \\
\text { including research experts and many Vietnam and abroad leading }\end{array}$ \\
\hline
\end{tabular}




\begin{tabular}{|l|l|}
\hline & $\begin{array}{l}\text { experts, with aim at promoting the research abilities as well as to } \\
\text { carry their prestige in scientific research. }\end{array}$ \\
\hline $\begin{array}{l}\text { Phenikaa University } \\
\text { (Phenikaa University, 2019) }\end{array}$ & $\begin{array}{l}\text { In May 2019, Phenikaa University announced their launching of 8 } \\
\text { strong research groups in the fields of Nanomaterials in biomedical, } \\
\text { environment \& energy, pharmaceutical chemistry \& bioactive } \\
\text { substances, smart information systems \& Nanosensors, Photonics \& } \\
\text { Optoelectronics, High Energy Physics \& Cosmology, and Grid data } \\
\text { analysis in Social Science. }\end{array}$ \\
\hline $\begin{array}{l}\text { Vietnam Interantioanl } \\
\text { University (VNU, 2014) }\end{array}$ & $\begin{array}{l}\text { VNU has an impressive number - more than 30 research groups in fields of } \\
\text { natural science-technology, and social sciences. Specially, The University } \\
\text { of Social Sciences and Humanities has more than 10 research groups. }\end{array}$ \\
\hline $\begin{array}{l}\text { University of Economics } \\
\text { (VNU) (UEB, 2020) }\end{array}$ & $\begin{array}{l}\text { In June 2020, the University of Economics announced a list of 5 of their } \\
\text { strong research groups which all reached the VNU-level group standard }\end{array}$ \\
\hline $\begin{array}{l}\text { Foreign Trade University } \\
\text { (FTU, 2017) }\end{array}$ & $\begin{array}{l}\text { On 11/01/2017, Foreign Trade University has launched 4 } \\
\text { research programs and 24 research groups, committed will published } \\
\text { 35 articles in the international academic journals at ISI category for } \\
\text { the period 2017-2019. }\end{array}$ \\
\hline
\end{tabular}

\section{EdLab Asia Center for Educational Research and Development History}

\subsection{A ballot initiative of kindred spirits}

EdLab Asia Center for Educational Research and Development (EdLab Asia) was established in September 2019 from the joint efforts of educational science researchers (including two authors of this summation). The word "EdLab" in the phrase EdLab Asia is the combination of prefix "Ed" in Education and suffix "Lab" in Laboratory. Although Laboratory is often considered something related to natural science instead of social science in Vietnam, we still decide to attach this suffix and fastforward to the old-school concept, which goes the same as developed countries (Falk \& Heckman, 2009; Webster \& Sell, 2014). More so, our "Lab" is two separating "Lab" acting as an ambassador conveying:

- EdLab Asia focuses on empirical studies instead of conceptual studies with aim at updating per second of changes in the current context of science and education.

- EdLab Asia focuses on the role of team work instead of working individually with the large number of all fixed and flexible investigators for different research topics.

\subsection{Mission}

At EdLab Asia, all "EdLabers" seem self-committed to drawing inspiration as well as changing Vietnamese educational doers' ways (all areas and levels) throughout academic research programs; science-education application as well as training, coaching on research methods, teaching methods, curriculum design, schooling psychology or educational governance and innovation.

\subsection{Organizational structure and operating model}

Up to now, EdLab Asia has had a total of 17 flexible staff members including $01 \mathrm{PhD}, 01 \mathrm{PhD}$ fellow, 05 Master students and 03 postgraduates. The Center accesses two research directions including higher education and K-12 education. All investigators, along with other research groups from some universities, institutions and research institutes such as Phenikaa University, Thai Nguyen University of Education, Academy of Ethnology, Thanh Do University, Phu Xuan University, Vietnam Institute of Educational Science, Hanoi National University, Education Magazine, Dong Thap University, 
Catholic Murcia University (Spain), Deakin University (Australia), Putra University Malaysia, Chinese Culture University (Taiwan), 3I Industrial Information Institute (Taiwan) participate in both of research directions, under the form of offline or online, depending on the specific characteristics of each project.

In general, each project comprises a project manager, research adviser, investigators and project assistants (Figure 2 below). When a project begins, it is usually carried out as below:

- A project manager is a person possessing at least a PhD level and that person has used to be the first author or corresponding author with many international publication experiences.

- Research advisers are these people whose qualifications are as high as a project manager and coordinate other research groups.

- Investigators (fixed or flexible staff members) often have the experience in international publishing as well as the proficiency in at least one stage in the research and publishing process. Investigators can take part in many different projects at the same time.

- Project assistants often are inexperienced newbies in the research field and take part in as assistants for investigators. Similar to their predecessors, they assist them in many different projects at the same time. It usually takes 3-6 months for a research assistant to become a fixed staff member.

- Every six months, investigators experience a two-way assessment to review the progressing process, identify specific goals and plans for the next six months.

Figure 2: EdLab Asia Research Project Model

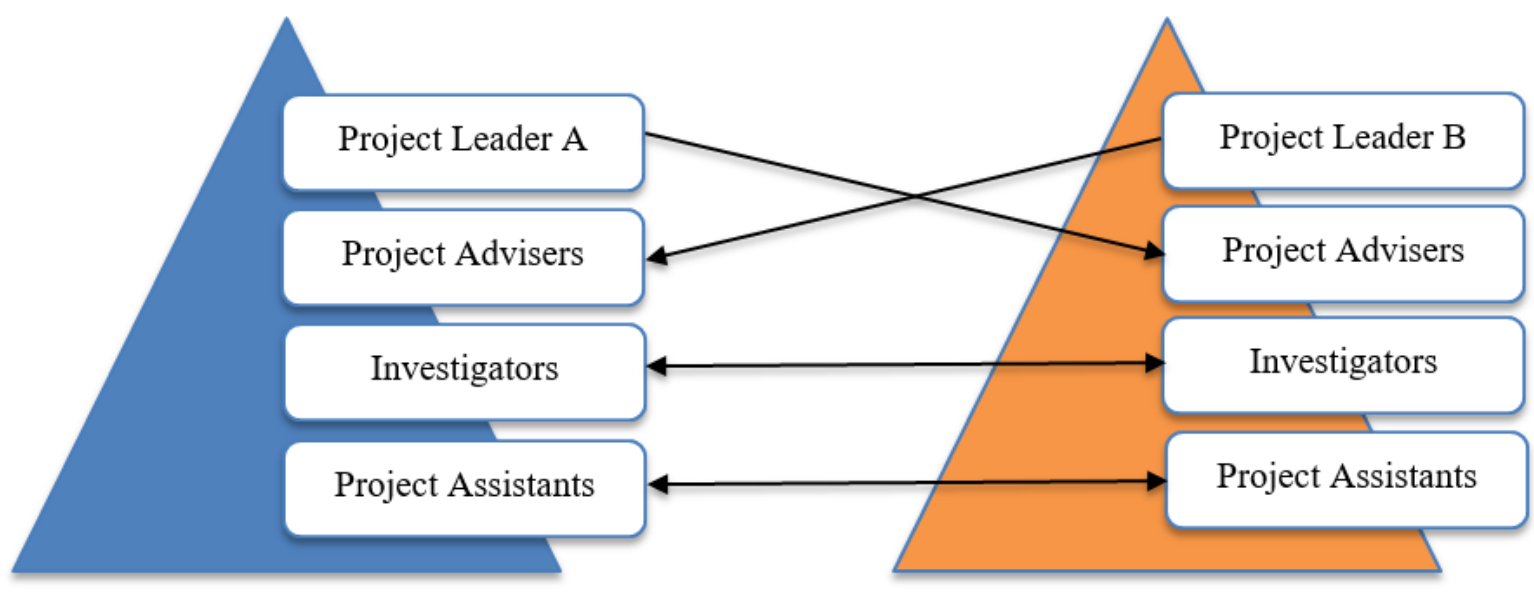

Currently, besides research and international publishing projects, EdLab Asia also implements training-coaching activities expanding all investigators' capacity (Figure 3 below). These activities conclude:

- Staff members regularly update their latest version via internal courses such as Social Sciences Introduction, Reading and Writing in Social Sciences, Applying SPSS Method or AMOS Method to conduct surveys based on SEM method, Econometrics, Bibliometrics or an array of methods for secondary data. In addition, staff members engage themselves in knowledgesupplementary workshops per month as either speakers or listeners.

- Staff members regularly shape their perception of reality via projects in which everyone assiduously cultivates each other. 


\section{Figure 3: Research Group Activities}

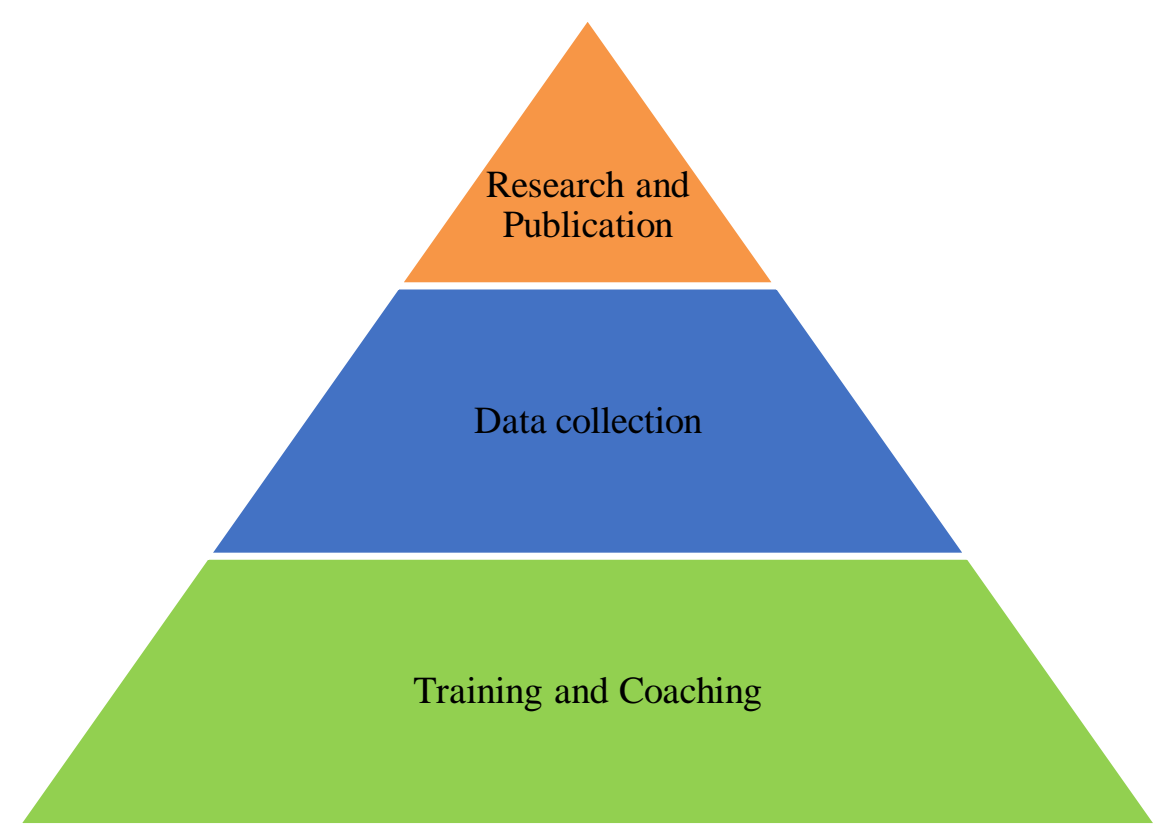

Together with training-coaching activities, we also put the emphasis on data construction as well as data collection. Owing to the coordination among research groups, we can promote this process effectively. However, gradually, we have high hopes for our own dataset so that we can proactively design long-term research projects as well as avoid the situation of insufficient data.

On the whole, Edlab Asia's operating processes for each research project are summarized through the concept of "RACI" (Responsible - Accountable - Consulted - Informed), in which each one takes their duty specifically, transparently and scientifically (Table 2 below).

Table 2: Research conducting and publishing process

\begin{tabular}{|c|c|c|c|}
\hline & Project leader/advisers & Investigators & Project assistants \\
\hline \multicolumn{4}{|l|}{ Research ideas } \\
\hline Choosing the proper topic & $X$ & & \\
\hline Choosing the proper method & $X$ & & \\
\hline Choosing the proper data & $X$ & & \\
\hline Cross-observation & $X$ & $X$ & $X$ \\
\hline \multicolumn{4}{|l|}{ Collecting and analyzing data } \\
\hline Collecting data & & $X$ & $X$ \\
\hline Data cleaning & & & $X$ \\
\hline
\end{tabular}




\begin{tabular}{|l|c|c|c|}
\hline Analyzing data & \multicolumn{2}{|c|}{$X$} & $X$ \\
\hline Cross-observation & $X$ & $X$ & $X$ \\
\hline Internal assessment & $X$ & $X$ & $X$ \\
\hline Working on manuscript & \multicolumn{3}{|c|}{} \\
\hline Manuscript distribution & $X$ & $X$ & $X$ \\
\hline Cross-observation & $X$ & $X$ & $X$ \\
\hline $\begin{array}{l}\text { References making and article } \\
\text { submission }\end{array}$ & $X$ & $X$ & \\
\hline Internal assessment & & $X$ & \\
\hline $\begin{array}{l}\text { Response to the editorial } \\
\text { staff/reviewer }\end{array}$ & & & \\
\hline Project coordinator & & & \\
\hline
\end{tabular}

\subsection{Achievements}

Table 3: EdLab Asia Achievement (2019-2020)

\begin{tabular}{|c|l|c|c|}
\hline No. & \multicolumn{1}{|c|}{ Article Title } & Index & Quality \\
\hline 1 & $\begin{array}{l}\text { Pham, H.-H. (2020). Coaching early-career social sciences } \\
\text { researchers to publish their first indexed publications: the Research } \\
\text { Coach in Social Sciences program as a model. Science Editing, 7(2), } \\
\text { 189-193. https://doi.org/10.6087/kcse.216 }\end{array}$ & ESCI \\
\hline 2 & $\begin{array}{l}\text { Hoang, A. D., Ta, N. T., Nguyen, Y. C., Hoang, C. K., Nguyen, T. } \\
\text { T., Pham, H. H., Nguyen, L. C., Doan, P. T., Dao, Q. A., \& Dinh, V. } \\
\text { H. (2020). Dataset of ex-pat teachers in Southeast Asia's intention to } \\
\text { leave due to the COVID-19 pandemic. Data in Brief, 31, 105913. } \\
\text { https://doi.org/10.1016/j.dib.2020.105913 }\end{array}$ & ESCI & Q2 \\
\hline 3 & $\begin{array}{l}\text { Trung, T., Hoang, A.-D., Nguyen, T. T., Dinh, V.-H., Nguyen, Y.- } \\
\text { C., \& Pham, H.-H. (2020). Dataset of Vietnamese student's learning } \\
\text { habits during COVID-19. Data in Brief, 30(10), 105682. } \\
\text { https://doi.org/10.1016/j.dib.2020.105682 }\end{array}$ & ESCI & \\
\hline 4 & $\begin{array}{l}\text { Vu, C.-T., Hoang, A.-D., Than, V.-Q., Nguyen, M.-T., Dinh, V.-H., } \\
\text { Le, Q.-A. T., Le, T.-T. T., Pham, H.-H., \& Nguyen, Y.-C. (2020). } \\
\text { Dataset of Vietnamese teachers' perspectives and perceived support } \\
\text { during the COVID-19 pandemic. Data in Brief, 31, } \\
\text { 105788.https://doi.org/10.1016/j.dib.2020.105788 }\end{array}$ & ESCI & \\
\hline 5 & $\begin{array}{l}\text { Vuong, Q. H., Napier, N. K., Ho, M. T., Nguyen, V. H., Vuong, T. } \\
\text { T., Pham, H. H., \& Nguyen, T. H. K. (2019). Effects of work } \\
\text { environment and collaboration on research productivity in } \\
\text { Vietnamese social sciences: evidence from 2008 to 2017 scopus } \\
\text { data. Studies in Higher Education, 44(12), 2132-2147. } \\
\text { https://doi.org/10.1080/03075079.2018.1479845 }\end{array}$ & Q2 \\
\hline 6 & $\begin{array}{l}\text { Trinh, T., Tran, T., Le, H., Nguyen, T., \& Pham, H. (2020). Factors } \\
\text { impacting international-indexed publishing among Vietnamese } \\
\text { educational researchers. Learned Publishing, leap.1323. } \\
\text { https://doi.org/10.1002/leap.1323 }\end{array}$ & SSCI & \\
\hline
\end{tabular}




\begin{tabular}{|c|c|c|c|}
\hline 7 & $\begin{array}{l}\text { Hoang, A.-D. (2019). Fantastic Educational Gaps and Where to Find } \\
\text { Them: LERB-A Model to Classify Inequity and Inequality. Journal } \\
\text { of International Education and Practice, 2(4), 19-28. } \\
\text { https://doi.org/10.30564/jiep.v2i4.1309 }\end{array}$ & & \\
\hline 8 & $\begin{array}{l}\text { Pham, H.-H., \& Vu, H.-M. (2019). Financing Vietnamese Higher } \\
\text { Education: From a Wholly Government-Subsidized to a Cost- } \\
\text { Sharing Mechanism. In N.-T. Nguyen \& L.-T. Tran (Eds.), } \\
\text { Reforming Vietnamese Higher Education. Education in the Asia- } \\
\text { Pacific Region: Issues, Concerns and Prospects (pp. 75-90). } \\
\text { Springer. https://doi.org/10.1007/978-981-13-8918-4_5 }\end{array}$ & & \\
\hline 9 & $\begin{array}{l}\text { Vu, T. B. T., Tran, N.-M., Do, T. M., \& Pham, H.-H. (2020). Firm } \\
\text { size, business sector and quality of accounting information systems: } \\
\text { Evidence from Vietnam. Accounting, 6(3), 327-334. } \\
\text { https://doi.org/10.5267/j.ac.2020.2.002 }\end{array}$ & & \\
\hline 10 & $\begin{array}{l}\text { Hoang, A.-D., Pham, H.-H., Nguyen, Y.-C., Nguyen, L.-K.- N., } \\
\text { Vuong, Q.-H., Dam, M. Q., Tran, T., \& Nguyen, T.-T. (2020). } \\
\text { Introducing a tool to gauge curriculum quality under Sustainable } \\
\text { Development Goal 4: The case of primary schools in Vietnam. } \\
\text { International Review of Education, 1-29. } \\
\text { https://doi.org/10.1007/s11159-020-09850-1 }\end{array}$ & ESCI & Q2 \\
\hline 11 & $\begin{array}{l}\text { Tran, Q. T., Pham, H. H., Vo, T. H., Luu, T. H., \& Nguyen, M. H. } \\
\text { (2019). Local governance, education and occupation education } \\
\text { mismatch: Heterogeneous effects on wages in a lower middle } \\
\text { income economy. International Journal of Educational Development, } \\
\text { 71, 102101.https://doi.org/10.1016/j.ijedudev.2019.102101 }\end{array}$ & SSCI & Q1 \\
\hline 12 & $\begin{array}{l}\text { Nguyen, T.-T., Trinh, T. P. T., Ngo, V. T. H., Hoang, N.-A., Tran, } \\
\text { T., Pham, H.-H., \& Bui, V.-N. (2020). Realistic Mathematics } \\
\text { Education in Vietnam: Recent Policies and Practices. International } \\
\text { Journal of Education and Practice, 8(1), 57- } \\
\text { 71.https://doi.org/10.18488/journal.61.2020.81.57.71 }\end{array}$ & & Q3 \\
\hline 13 & $\begin{array}{l}\text { Tran, T., Trinh, T.-P.-T., Le, C.-M., Hoang, L.-K., \& Pham, H.-H. } \\
\text { (2020). Research as a Base for Sustainable Development of } \\
\text { Universities: Using the Delphi Method to Explore Factors Affecting } \\
\text { International Publishing among Vietnamese Academic Staff. } \\
\text { Sustainability, 12(8), 3449. https://doi.org/10.3390/su12083449 }\end{array}$ & SCIE/SSCI & $\mathrm{Q} 2$ \\
\hline 14 & $\begin{array}{l}\text { Pham, H.-H., Lai, S. L., \& Vuong, Q.-H. (2019). The Role of } \\
\text { Subjective Task Value in Forming Satisfaction and Loyalty Among } \\
\text { Vietnamese International Students: A Structural Equation Model. } \\
\text { The Asia-Pacific Education Researcher, 28(5), 399-409. } \\
\text { https://doi.org/10.1007/s40299-019-00439-3 }\end{array}$ & SSCI & Q2 \\
\hline 15 & $\begin{array}{l}\text { Vuong, Q.-H., Do, M.-T., Pham, T.-V.-A., Do, T.-A., Doan, P.-T., } \\
\text { Hoang, A.-D., Ta, T.-H., Le, Q.-A., \& Pham, H.-H. (2020). The } \\
\text { status of educational sciences in Vietnam: A bibliometric analysis } \\
\text { from Clarivate Web of Science database between } 1991 \text { and } 2018 . \\
\text { Problems of Education in the } 21 \text { st Century, 78(4), 644-662. } \\
\text { https://doi.org/10.33225/pec/20.78.644 }\end{array}$ & ESCI & Q3 \\
\hline
\end{tabular}




\begin{tabular}{|c|l|c|c|}
\hline 16 & $\begin{array}{l}\text { Tran, T., Hoang, A.-D., Nguyen, Y.-C., Nguyen, L.-C., Ta, N.-T., } \\
\text { Pham, Q.-H., Pham, C.-X., Le, Q.-A., Dinh, V.-H., \& Nguyen, T.-T. } \\
\text { (2020). Toward Sustainable Learning during School Suspension: } \\
\text { Socioeconomic, Occupational Aspirations, and Learning Behavior of } \\
\text { Vietnamese Students during COVID-19. Sustainability, 12(10), } \\
\text { 4195. https://doi.org/10.3390/su12104195 }\end{array}$ & SCIE/SSCI & Q2 \\
\hline 17 & $\begin{array}{l}\text { Cao, T. Q., \& Chieu, Q. K. (in press). To Return or Not to Return: A } \\
\text { Dilemma of Two Overseas Vietnamese Students in the Netherlands } \\
\text { amidst the Coronavirus Outbreak.Journal of International Students }\end{array}$ & ESCI & Q2 \\
\hline 18 & $\begin{array}{l}\text { Nguyen, N.-A. T., Cao, T. Q., \& Pham, H.-H. (2020). Impact of the } \\
\text { New Southbound Policies in International Students on Taiwan: An } \\
\text { Exploratory Study from Vietnamese Oversea Students. In P. Le Ha } \\
\text { \& D. Ba Ngoc (Eds.), Higher Education in Market-Oriented Socialist } \\
\text { Vietnam. Springer International Publishing. } \\
\text { https://doi.org/10.1007/978-3-030-46912-2 }\end{array}$ & & \\
\hline
\end{tabular}

\section{Conclusion and recommendation}

Over the last 10 years, Vietnamese government as well as group researchers have attached great importance to international integration in scientific research. Especially, all researchers in social sciences have targeted their great effort at making an encouraging remark with the initial surge of results. Inspired by that context, EdLab Asia formulation has continued its tradition by doing:

(i) First, to optimize the use of resources, we have cooperated closely with research groups, both at home and abroad.

(ii) Second, to avoid the "sedentary" working behavior, we always organize research groups flexibly within inner and outer staff members, either offline or online.

(iii) Third, to possess our dataset (secondary data) independently in the nearest future, we actively access and supplement our data repository in abundance from topic to the fabric of space and time.

(iv) Fourth, to enhance research skills and capacity as well as strengthen the links among staff members, we continuously conduct working projects in two dimensions: From the vertical flow, a project leader discuss and spearhead the project direction for partakers (investigators and project assistants) or from the horizontal flow, project leaders discuss each other and propagandize for investigators, then investigators promulgate for project assistants afterwards.

(v) Finally, to facilitate broader participation for all project members, we break each project into each specific part as specialized as possible.

Since the foundation, our gut feeling has been telling us to reach the wider world of social science without being satisfied with elementary achievements. We look forward to receiving comments and reviews from other research groups in this field as well as research groups from other fields. Last but not least, we would share some words from Vu Ha Van Profession: "We want to plant one or two $100 \mathrm{~m}$ trees, certainly, we have to possess a forest of 30m tree" (Phan, 2018). Attaching his perspective into our social sciences context, it means that in order to create outstanding scientists (100m trees), there must be many good scientists around (trees 30m high). Nevertheless, we have not regarded ourselves as $100 \mathrm{~m}, 50 \mathrm{~m}$ or $30 \mathrm{~m}$ trees and we believe that in every forest, each tree has its own merits. Our duty is somehow the same as a $5 \mathrm{~m}$ or $3 \mathrm{~m}$ tree. Throughout the growth process, we continue nurturing and developing our seeds to become $1 \mathrm{~m}-2 \mathrm{~m}$ trees.

\section{References}


Falk, A., \& Heckman, J. J. (2009). Lab Experiments Are a Major Source of Knowledge in the Social Sciences. Science, 326(5952), 535-538. https://doi.org/10.1126/science.1168244

FTU. (2017). Lễ ra mắt Các chưong trình nghiên cứu, nhóm nghiên cứu và Hội thảo "Sừ dụng dũ liệu StoxPlus trong nghiên cưu thưc nghiệm.” http://www.ftu.edu.vn/chuyên-mục-khác2/64su-kien-tieu-bieu/1212-lễ-ra-mắt-các-chương-trình-nghiên-cứu,-nhóm-nghiên-cứu-và-hộithảo-“sử-dụng-dữ-liệu-stoxplus-trong-nghiên-cứu-thực-nghiệm".html

Milojevi, S. (2014). Principles of scientific research team formation and evolution. Proceedings of the National Academy of Sciences, 111(11), 3984-3989. https://doi.org/10.1073/pnas.1309723111

Nguyen, H. C., Nguyen, T. M. L., Tran, T., \& Nguyen, T. T. (2020). Bibliographic and content analysis of articles on education from Vietnam indexed in Scopus from 2009 to 2018. Science Editing, 7(1), 45-49. https://doi.org/10.6087/kcse.188

Pham, H.-H. (2020). Coaching early-career social sciences researchers to publish their first indexed publications: the Research Coach in Social Sciences program as a model. Science Editing, 7(2), 189-193. https://doi.org/10.6087/kcse.216

Dang, P. (2018). Trí thức Việt Nam - một lát cắt theo dòng lich sủ Kỳ cuối: Giáo su Vũ Hà Văn (khoa Toán, Đại học Yale, Mỹ): "Trong rùng, phải có nhiều cây 30m mới hy vong có được một, hai cây $100 m$...." An Ninh Thế Giới. http://antgct.cand.com.vn/Tro-chuyen-cuoi-thang/Ky-cuoiGiao-su-Vu-Ha-Van-khoa-Toan-Dai-hoc-Yale-My-Trong-rung-phai-co- nhieu-cay-30mmoi-hy-vong-co-duoc-mot-hai-cay-100m-497431/

Phenikaa University. (2019). Trường Đại học PHENIKAA công bố quyết định và ra mắt 8 nhóm nghiên cúu mạh. https://phenikaa-uni.edu.vn/chitiet/su-kien/truong-dai-hoc-phenikaa-congbo-quyet-dinh-va-ra-mat-8-nhom-nghien-cuu-manh

TLU. (2020). Truờng Đại học Thủy lợi ra mắt 4 nhóm nghiên cứu mạn. http://www.tlu.edu.vn/nghien-cuu/truong-dai-hoc-thuy-loi-ra-mat-4-nhom-13208

Tran, T., Trinh, T.-P.-T., Le, C.-M., Hoang, L.-K., \& Pham, H.-H. (2020). Research as a Base for Sustainable Development of Universities: Using the Delphi Method to Explore Factors Affecting International Publishing among Vietnamese Academic Staff. Sustainability, 12(8), 3449. https://doi.org/10.3390/su12083449

UEB. (2020). Các nhóm nghiên cứu mạnh cấp ĐHQGHN của Truờng Đại học Kinh tế. \%0ACác nhóm nghiên cứu mạnh cấp ĐHQGHN của Trường Đại học Kinh tế

VNU. (2014). Phát triển nhóm nghiên cưu trong trường đại học - Xu thế tất yếu. VNU. https://www.vnu.edu.vn/ttsk/?C1657/N16259/Phat-trien-nhom-nghien-cuu-trong-truongdai-hoc--Xu-the-tat-yeu.htm

Vuong, Q.-H., Do, M.-T., Pham, T.-V.-A., Do, T.-A., Doan, P.-T., Hoang, A.-D., Ta, T.-H., Le, Q.A., \& Pham, H.-H. (2020). The status of educational sciences in Vietnam: A bibliometric analysis from Clarivate Web of Science database between 1991 and 2018. Problems of Education in the 21 st Century, 78(4), 644-662. https://doi.org/10.33225/pec/20.78.644

Vuong, Q. H. (2019). The harsh world of publishing in emerging regions and implications for editors and publishers: The case of Vietnam. Learned Publishing, 32(4), 314-324. https://doi.org/10.1002/leap.1255

Webster, M., \& Sell, J. (2014). Laboratory Experiments in the Social Sciences (M. Webster \& J. Sell (eds.); 2nd ed.). Elsevier. https://doi.org/10.1016/C2011-0-07562-2 